\title{
Optimum Renewable Fraction for Grid-connected Photovoltaic in Office Building Energy Systems in Indonesia
}

\author{
Ayong Hiendro, Ismail Yusuf, F. Trias Pontia Wigyarianto, Kho Hie Khwee, Junaidi \\ Department of Electrical Engineering, Tanjungpura University, Pontianak, Indonesia
}

\begin{tabular}{l}
\hline \hline Article Info \\
\hline Article history: \\
Received May 17, 2018 \\
Revised Aug 27, 2018 \\
Accepted Sep 3, 2018 \\
\hline Keyword: \\
Cost and benefit \\
Grid-connected PV system \\
HOMER \\
Office building \\
Renewable fraction \\
\hline
\end{tabular}

\begin{abstract}
This paper analyzes influences of renewable fraction on grid-connected photovoltaic (PV) for office building energy systems. The fraction of renewable energy has important contributions on sizing the grid-connected PV systems and selling and buying electricity, and hence reducing net present cost (NPC) and carbon dioxide $\left(\mathrm{CO}_{2}\right)$ emission. An optimum result with the lowest total NPC for serving an office building is achieved by employing the renewable fraction of $58 \%$, in which $58 \%$ of electricity is supplied from the PV and the remaining $42 \%$ of electricity is purchased from the grid. The results have shown that the optimum grid-connected PV system with an appropriate renewable fraction value could greatly reduce the total $\mathrm{NPC}$ and $\mathrm{CO}_{2}$ emission.
\end{abstract}

Copyright $\odot 2018$ Institute of Advanced Engineering and Science. All rights reserved.

\section{Corresponding Author:}

Ayong Hiendro,

Department of Electrical Engineering, Tanjungpura University,

Jl. Jenderal Ahmad Yani, Pontianak, Kalimantan Barat, Indonesia.

Email: ayong.hiendro@ee.untan.ac.id

\section{INTRODUCTION}

Exploitation and utilization of renewable energy resources for buildings are parts of Indonesia's energy conservation policies to provide and develop renewable energy in order to reduce fossil fuel consumption and hence, reducing $\mathrm{CO}_{2}$ pollution. Renewable energy systems are capable of powering buildings without connection to a utility grid. However, connecting renewable energy to the utility grid offers more reliable electricity supply [1], [2].

In recent years, the PV technology prices tend to decline [3], [4], while the prices of conventional fossil fuel-based electricity have been gradually increased. Moreover, the growth rate of grid-connected PV electricity systems rises significantly every year and dominates the PV electricity market [5].

According to the report in [6], [7], office buildings in Indonesia spend 15.2 TWh of electricity and require electrical energy, on average, by $250 \mathrm{kWh} / \mathrm{m}^{2} /$ year. The total electricity consumption is dominated by air conditioning and lighting equipments. These two components consume about $80 \%$ of the total electricity for the buildings. However, most of the electric power demands of the office buildings are still dependent to the utility grid.

From an economic standpoint, the difference between prices of electricity purchased and sold is a substantial determinant in designing a grid-connected PV system [8], [9]. In the grid-connected PV system, an office building is hooked up to both the utility grid and the PV system. The building is billed if the electric energy consumption is in excess of the amount generated by the PV. The building could be supplied by a portion of energy from the PV during sunny days, and powered from the utility grid during nights or on cloudy hours when the PV output is insufficient. If there is any surplus electricity from the PV, it will be sent to the utility grid.In such way, the grid-connected system could use real-time electricity pricing methods via net-metering mechanisms for the billing process [10], [11]. It gives customer benefits by reducing the monthly bill [12], if the size of the PV in the grid-connected PV system is properly estimated. The parameter 
describing the portion of electricity produced by the PV in the grid-connected PV system is the renewable fraction.

There are many investigation reports about economic point of grid-connected PV systems for buildings. Davi et al. [13] investigated on different scenarios of investment costs, discount rates and electricity tariffs for buildings with grid-connected PV system. Ayadi et al. [14] reported their economic analysis on payback period and internal rate of return for university building with grid-connected PV system. Economical and environmental analysis on grid-connected PV system for institutional building was investigated by Allouhi et al. [15]. Kazem et al. and Omar et al. investigated economic feasibility of gridconnected PV system for home buildings [16], [17]. Other economic analysis of the paid incentives and selling the electricity for economic profit of PV grid-connected system on buildings was reported by Orioli et al. in ref [18].

However, they did not analyze the influences of renewable fraction in their works. This paper intends to fill the gaps observed in the literature concerning the analysis of the effects of renewable fraction values on the size of a grid-connected PV system for the office building in order to suppress the total NPC and $\mathrm{CO}_{2}$ emission of the electricity production.

\section{BACKGROUND INFORMATION}

\subsection{Load Profile}

The load profile of a typical office building in Indonesia is presented in Figure 1. The load profile indicates that the peak load of the office building is about $849 \mathrm{~kW}$ with energy consumption of 9,165 $\mathrm{MWh} /$ day. The average annual electricity consumption is $250.96 \mathrm{kWh} / \mathrm{m}^{2} /$ year.

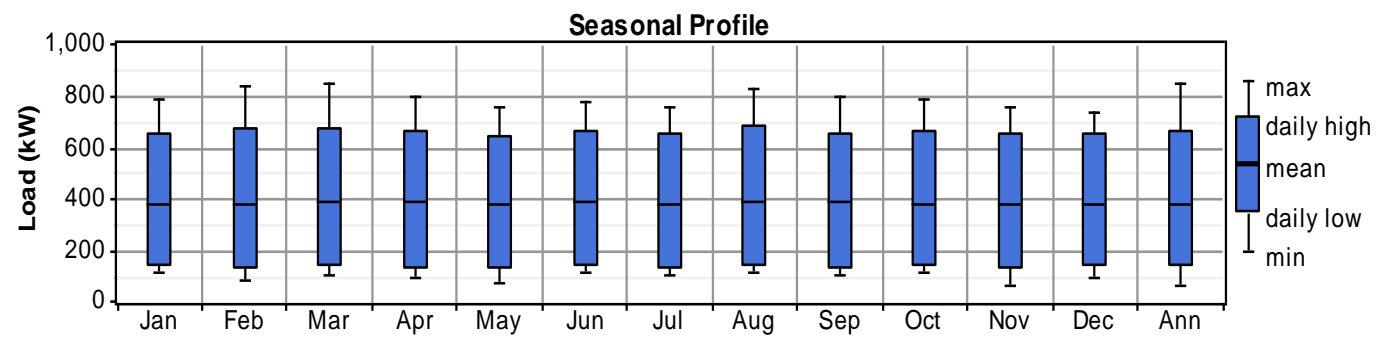

Figure 1. Monthly load profile of office building

The electricity demand in office building varies slightly each month, and this is dependent to the business activities, instead of the weather conditions. Office building in tropical climate region, such as Indonesia, has high cooling demands.Air conditioning is the major electricity consumers in the office building.Lighting and office equipments (laptop PCs, desktop PCs, printers, photocopiers) are other significant source of electricity use in the office building. The small amount of electricity is required by miscellaneous equipments such as: lifts, water pumps, and ventilation fans. Figure 2 shows the distribution of electricity usage in the office building.

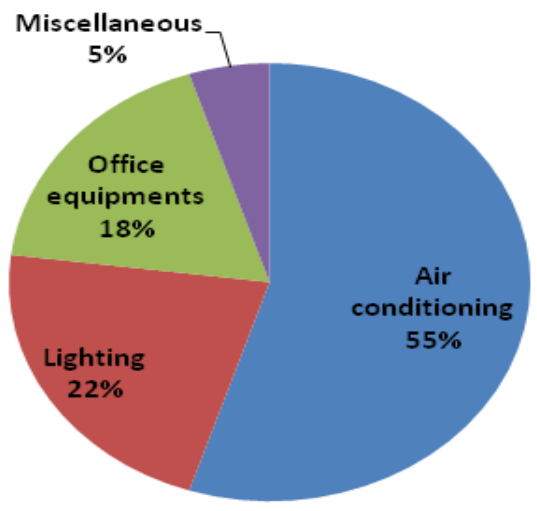

Figure 2. Electricity consumption distribution 


\subsection{Solar Radiation}

In this work, HOMER [19] is employed for simulations. Solar radiation (in $\mathrm{kWh} / \mathrm{m}^{2} / \mathrm{day}$ ) and the clearness index (a dimensionless number between zero and one) are used as the input data as shown in Figure 3. The average solar radiation in Pontianak (Indonesia) is $5.12 \mathrm{kWh} / \mathrm{m}^{2} /$ day according to data accessed from NASA [20]. Solar radiation is high during February through to September, while it is relative low in January, October, November and December.

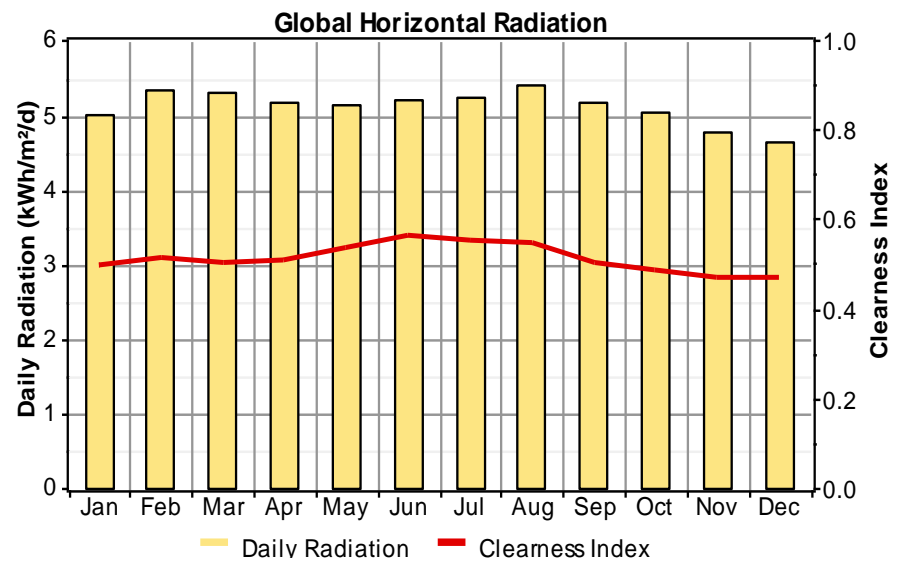

Figure 3. Solar radiation data

\section{SYSTEM CONFIGURATION}

The grid-connected PV system as seen in Figure 4 consists of PV array, inverter, grid, and load. The grid-connected PV system does not need batteries as the energy storage. The surplus electricity produced by the PV is sold to the grid. On the other hand, the grid will cover all electricity loads when the PV could not supply electricity at night or during cloudy hours

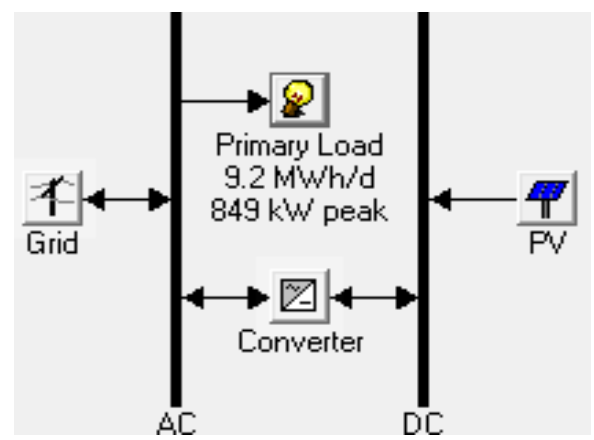

Figure 4. System configuration

\subsection{PV Array}

The PV array is sized dependent to the peak load demand and the renewable fraction required. The capital investment of PV arrays including construction and installation costs is set at $\$ 2000 / \mathrm{kW}$ [21]. The estimated O\&M cost is $\$ 10 / \mathrm{kW}$ per year, while the PV array lifetime is 20 years. The PV cost data is provided in Table 1.

Table 1. PV and Inverter Data

\begin{tabular}{lcr}
\hline & PV & Inverter \\
\hline Lifetime & $20 \mathrm{yr}$ & $15 \mathrm{yr}$ \\
Efficiency & $90 \%$ & $98 \%$ \\
Capital cost per kW & $\$ 2000$ & $\$ 200$ \\
Replacement cost per kW & $\$ 1500$ & $\$ 150$
\end{tabular}

Int J Pow Elec \& Dri Syst, Vol. 9, No. 4, December 2018 : 1866 - 1874 


\subsection{Inverter}

O \& M cost per kW per year $\quad \$ 10 \quad \$ 15$

A grid-connected PV system for commercial-scale applications (10kW-2MW) usually uses non module-level power electronics (MLPE) inverters as the DC-to-AC interfaces. Currently, the average price of the inverter is $\$ 170 / \mathrm{kW}$ [22], and it becomes $\$ 200 / \mathrm{kW}$ if the labor cost is included. Inverter O\&M cost is estimated to be $\$ 15 \mathrm{~kW} / \mathrm{yr}$ and it is considered to last for 15 years [22], [23].

The inverter size depends on DC-to-AC ratio $(R)$. If the PV array's DC rating is higher than the inverter's AC rating, the DC-to-AC ratio will be larger than $1(R>1)$. The DC-to-AC ratio for both residential and commercial PV systems is set to $R=1.15$ as recommended by Fu et al. in NREL [22], in order to increase the inverter utilization during the sunniest periods. Over sizing inverter would increase costs to the system but also increase the amount of electricity generated. Although there are no batteries to store excess electricity generated by the PV, but no excess electricity would be dump, since all electricity is used by loads and sold to the grid.The inverter data is also summarized in Table 1.

\subsection{Pricing}

Electric price is regulated by the govenment via tariff adjusmant mechanisms which is based on nominal exchange rate, fossil fuel price, and inflation rate [24]. Non-subsidized electricity tariff at off-peak hours is $\$ 0.113 / \mathrm{kWh}$. The tariff is multiplied by a constant of $k$ for shoulder and peak hours, where $1.4 \leq k \leq$ 2.0.In this study, the price of electricity bought from the grid is set to $\$ 0.113 / \mathrm{kWh}$. The price becomes $\$$ $0.158 / \mathrm{kWh}$ and $\$ 0.226 / \mathrm{kWh}$ at shoulder and peak hours, respectively. The demand rate (in $\$ / \mathrm{kW} / \mathrm{month}$ ) for off-peak, soulder, and peak hours are also based on the regulation. The sellback rate for PV electricity is $\$$ $0.108 / \mathrm{kWh}$ as ruled in [25].Selling and buying the electricity generated by the PV system is a part of Indonesia government policy in order to enhance utilization rate of renewable energy resources for electricity.

\subsection{Total Net Present Cost}

The total capital cost $C_{c}$ for the grid-connected PV system is given by

$$
C_{c}=\mathrm{C}_{c, \text { grid }}+C_{c, p V}+C_{c, i n v}+C_{c, f}
$$

Where $C_{c, \text { grid }}, C_{c, P V}, C_{c, \text { inv }}$ and $C_{c, f}$ are the capital costs of grid, PV, inverter, and other system capital cost, respectively. The operating and maintenance $\operatorname{cost} C_{o}$ is the operating and maintenance costs of all components and the other system operating and maintenance cost, which is defined as follows:

$$
C_{0}=C_{o, g r i d}+C_{0, p V}+C_{0, i n v}+C_{o, f}
$$

The total NPC is the present value of all the costs minus the present value of all the revenues over the project lifetime. The costs include capital costs, operating and maintenance costs, and the costs of buying electricity from the grid. Revenues include the revenues of selling electricity to the grid and the salvage value. The total NPC can be defined as

$$
C_{N P C, t o t}=C_{a n n, t o t} / \operatorname{CRF}\left(i, R_{\text {proj }}\right)
$$

Where $C_{a n n, t o t}$ is the total annualized cost, $i$ is the annual real interest rate $(\%), R_{\text {proj }}$ is the project lifetime (yr), and $\mathrm{CRF}()$ is a function of the capital recovery factor. The capital recovery factor is a ratio to obtain the present value of an annuity. The capital recovery factor is expressed by

$$
\operatorname{CRF}(i, N)=\frac{i(1+i)^{N}}{\left(1+\hat{i}^{N}-1\right.}
$$

where $N$ is number of years.

\subsection{Renaweble Fraction}

The renewable fraction is the portion of total electricity production which is generated by renewable resources. The equation of renewable fraction is:

$$
\text { Renewable Fraction }=\frac{\text { Renewable Electricity } \text { Production }}{\text { Total Electricity } \text { Production }}
$$




\section{RESULT AND ANALYSIS}

In this paper, the system performance is set at an unmet load of $0 \%$. The office building's electrical load is served by both PV generator and electrical grid. The excess electricity produced by the PV is not dumped, but it is sold to the grid via the net-metering mechanism. The PV array parameters used in simulation are: $T_{c, N O C T}=47^{\circ} \mathrm{C}, \alpha_{p}=-0.43 \% /{ }^{\circ} \mathrm{C}, \eta_{m p, S T C}=15.67 \%$, and derating factor of the PV, $f_{P V}=90 \%$. The environmental factors such as ground reflectance and ambient temperature are included into computation in order to obtain accurate results. The ground reflectance is $20 \%$ as measured on the location.

\subsection{PV Sizes}

Figure 5 describes the effect of renewable fraction on the PV size. The renewable fraction of $0 \%$ means that all load demand is supplied by the grid without PV penetrations. The renewable fraction of $100 \%$ indicates the electrical load is served by a stand-alone PV. However, the stand-alone PV system without energy storage equipments could not be applied for 24-hour electricity service.

Increasing the renewable fraction would reduce the need for electricity from the grid. The higher renewable fraction requires the larger sizes of PV array and inverter in order to supply electricity from the PV to the building. The PV size increases significantly when the renewable fraction is higher than $70 \%$, as shown in Figure 5. At the renewable fraction of 60\%, the grid-connected PV system needs $1.7 \mathrm{MW}$ of PV array. It requires 2.45 MW, 3.8 MW, and 7.75 MW of PV arrays for 70\%, 80\%, and $90 \%$ of renewable fraction, respectively. The PV size for renewable fraction of $90 \%$ is twice of it is for the renewable fraction of $80 \%$

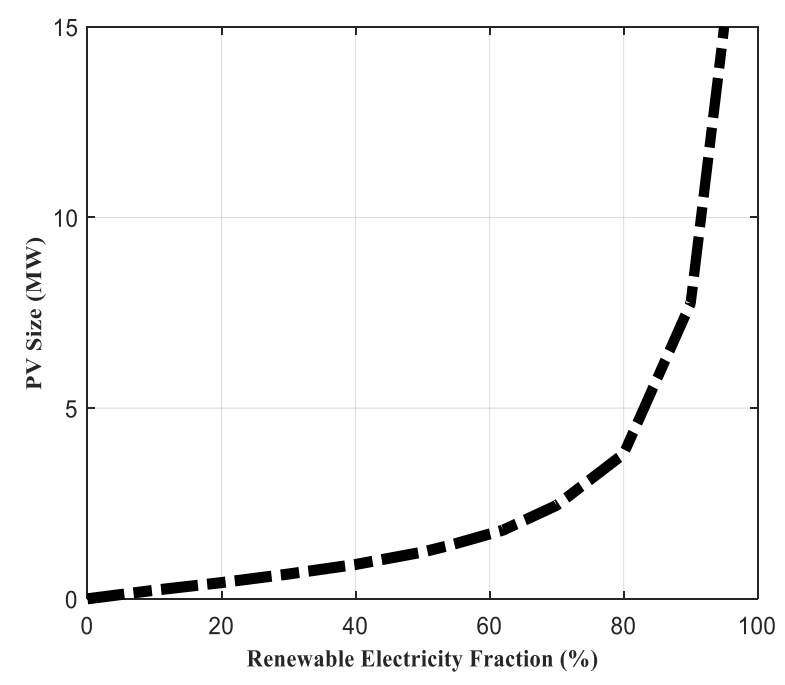

Figure 5. PV size vs. renewable fraction

\subsection{Net Purchases}

Electricity purchased from and sold to the grid according to the renewable fraction is shown in Figure 6 and 7. The amount of electricity purchased from the grid decreases with increasing of the percentage of renewable fraction of the system. On the other hand, the system could sell more electricity to the grid when the renewable fraction is higher. The difference between the electricity sold and purchased prices is the net purchases. A negative value of the net purchases indicates that the system sells more electricity to the grid than it is purchased from the grid. As shown in Figure. 8, the net purchases value is negative after the renewable fraction becomes greater than $66 \%$. At renewable fraction of $67 \%$, the annually electricity purchased from the grid is $1,667,075 \mathrm{kWh} / \mathrm{yr}$ and the electricity sold to the grid is $1,701,991 \mathrm{kWh} / \mathrm{yr}$. This results in the net purchases of $-34,916 \mathrm{kWh} / \mathrm{yr}$. However, the high grid sales earned does not mean that the NPC of the system becomes low. The NPC of the grid-connected PV system is indeed not only influenced by the net purchases, but also by the total costs of the PV array and inverter. Melodi et al. [26] observed costs of the PV as renewable energy sources for the grid-connected system. The PV array and inverter have the high initial capital costs. Therefore, the PV and inverter costs and the level of PV penetration contribute to the grid connected PV system costs. 


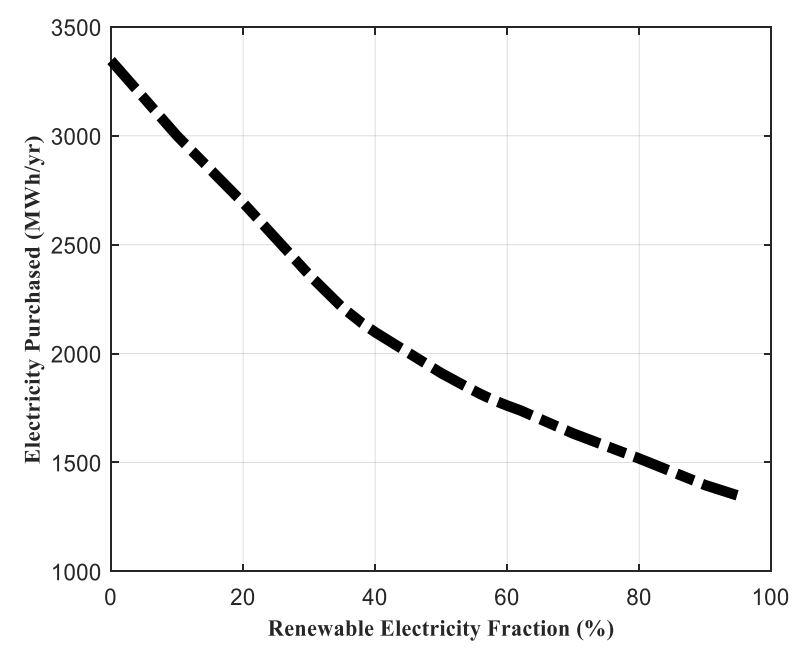

Figure 6. Electricity purchased vs. renewable fraction

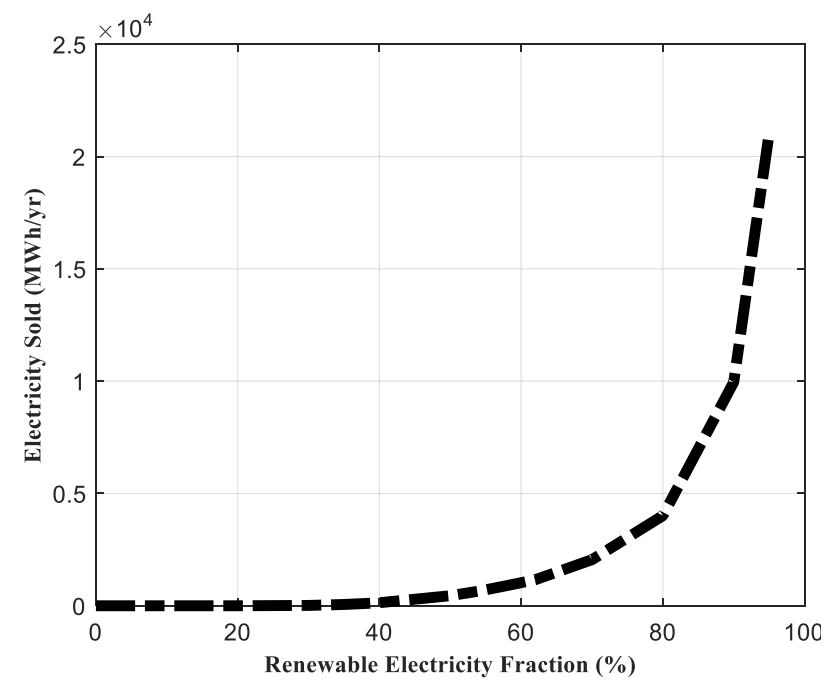

Figure 7. Electricity sold vs. renewable fraction

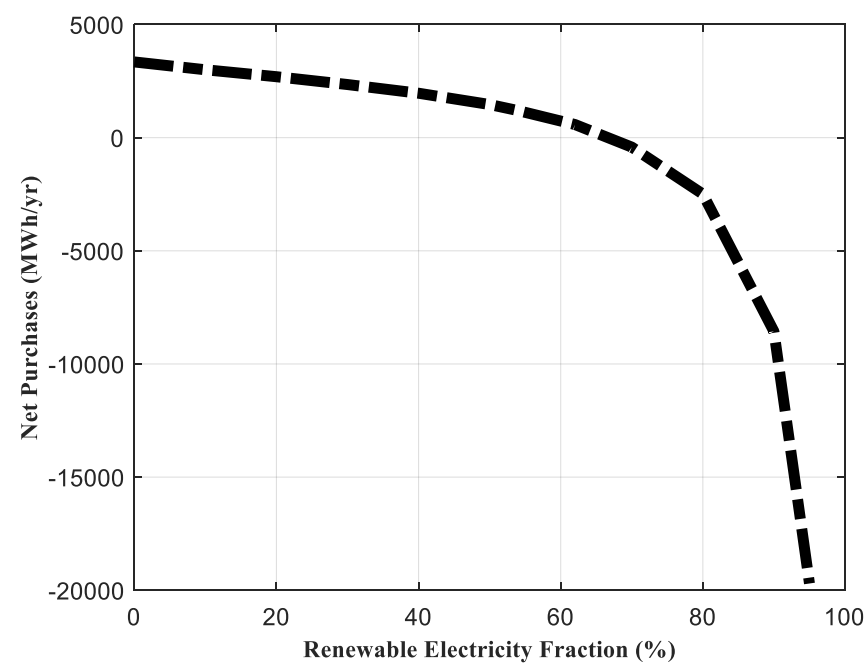

Figure 8. Net purchases vs. renewable fraction 


\subsection{Net Present Cost and Optimum Grid-Connected PV System}

From Figure 9, it is observed that the NPC decreases with increasing of the PV energy penetrations until it is reached by the renewable fraction of $58 \%$. The NPC rises dramatically after the renewable fraction of the system is greater than $58 \%$. It has been mentioned that the revenues from selling electricity are very high when the renewable fraction is above $66 \%$. However, the revenues from sales are not enough to cover the total costs of the PV system due to the large PV array and inverter sizes when the renewable fraction is increased.

The best NPC of grid-connected PV system is reached at the renewable fraction of $58 \%$. In this condition, $58 \%$ of electricity is produced by PV arrays while the grid supplies the remaining $42 \%$ of production to meet the office building's load. The PV array of $1.6 \mathrm{MW}$ produces $2,508,459 \mathrm{kWh} / \mathrm{yr}$ and contributes $58 \%$ of the total electricity, while the grid supplies the remaining $42 \%$ of demands. The surplus electricity from the PV is sold to the grid for revenues. At the renewable fraction of $58 \%$, the electricity purchased from the grid is $1,785,646 \mathrm{kWh} / \mathrm{yr}$, while the grid sales revenue is $898,703 \mathrm{kWh} / \mathrm{yr}$. As the results, cost of the grid is $\$ 3,335,497$, and costs for both PV array and inverter are $\$ 3,934,157$, and hence the NPC of the grid-connected PV system becomes $\$ 7,269,654$. After all, the NPC of the grid-connected PV system is lower than the NPC of $\$ 7,399,133$, when the building buys all electricity from the grid (at renewable fraction of $0 \%$ ), leading to save about $\$ 129,276$ as the result of selling and buying electricity via net-metering. Table 2 summarizes the optimization results for the optimum grid-connected PV system and the utility grid.

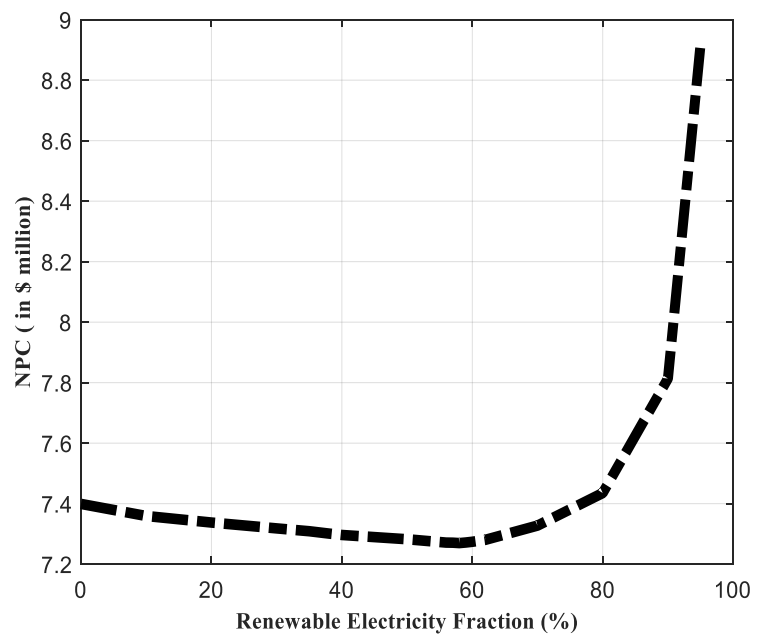

Figure 9. Total NPC vs. renewable fraction

Carbon dioxide emission also becomes an interesting environmental factor for a grid-connected PV system. For $\mathrm{CO}_{2}$ emission factor of $721 \mathrm{~g} / \mathrm{kWh}$ [27], the grid-connected PV system produces $\mathrm{CO}_{2}$ emission of $677,129 \mathrm{~kg} / \mathrm{yr}$. This value is lower than the CO2 emission of 2,411,911 kg/yr which is produced by the conventional utility grid. It is clear that the grid-connected PV system has an important contribution to reduce $\mathrm{CO}_{2}$ emission. The grid-connected PV system will get more benefits if the government gives incentive for emitting low proportion of $\mathrm{CO}_{2}$ pollutant.

Table 2. Optimization results

\begin{tabular}{lrr}
\hline & Renewable fraction $(\%)$ \\
\hline & 0 & 58 \\
Primary load $(\mathrm{kWh} / \mathrm{yr})$ & $3,345,227$ & $3,345,227$ \\
PV size $(\mathrm{kW})$ & 0 & 1600 \\
PV production $(\mathrm{kWh} / \mathrm{yr})$ & 0 & $2,508,459$ \\
Grid purchases $(\mathrm{kWh} / \mathrm{yr})$ & $3,345,227$ & $1,785,646$ \\
Grid sales $(\mathrm{kWh} / \mathrm{yr})$ & 0 & 898,703 \\
PV costs $(\$)$ & 0 & $3,427,398$ \\
Inverter costs $(\$)$ & 0 & 506,759 \\
Grid costs $(\$)$ & $7,399,133$ & $3,335,497$ \\
\hline
\end{tabular}




\section{CONCLUSION}

The renewable fraction influences on PV array and inverter sizing, and also on cost and benefit from selling and buying electricity and the net purchase, the total NPC and $\mathrm{CO}_{2}$ emissions in the grid-connected PV system. An optimum result, with the lowest NPC for serving the office building with a demand load of $3,345,227 \mathrm{kWh} / \mathrm{yr}$, is obtained by implementing 1.6 MW PV size (with the ratio of $R=1.15$ ) and renewable fraction of 58\%. From an environmental standpoint, the rate of $\mathrm{CO}_{2}$ emission is reduced by $72 \%$ in the case of the grid-connected PV system, compared to the conventional electricity grid. The grid-connected PV system offers the greater economic and environmental benefits than the utility grid without PV for the office building electricity

\section{REFERENCES}

[1] O. Erdinc, M. Uzunoglu, "Optimum Design of Hybrid Renewable Energy Systems: Overview of Different Approaches," Renewable and Sustainable Energy Reviews, vol. 16, pp. 1412-1425, 2012.

[2] S.W. Shneen, "Advanced Optimal for Power-Electronic Systems for the Grid Integration of Energy Sources," Indonesian Journal of Electrical Engineering and Computer Science, vol. 1, pp. 543-555, 2016.

[3] J.L. Prol, K.W. Steininger, "Photovoltaic Self-Consumption Regulation in Spain: Profitability Analysis and Alternative Regulation Schemes," Energy Policy, vol. 108, pp.742-754, 2017.

[4] R.L. Arantegui , A. Jäger-Waldau," Photovoltaics and Wind Status in the European Union after the Paris Agreement," Renewable and Sustainable Energy Reviews, vol. 81, pp. 2460-2471, 2018.

[5] M.A. Eltawil, Z. Zhao, "Grid-Connected Photovoltaic Power Systems: Technical and Potential Problems - A Review," Renewable and Sustainable Energy Reviews, vol. 14, pp.112-129, 2010.

[6] S. Howes, R. Davies, "Survey of Recent Developments," Bulletin of Indonesian Economic Studies, vol. 50, pp. 157-183, 2014.

[7] GBCI Technology and Rating Division, Greenship Existing Building Version 1.1., Green Building Council Indonesia, 2016.

[8] J.C. Hernandez, P.G. Vidal, G. Almonacid, "Photovoltaic in Grid-Connected Buildings,Sizing and Economic Analysis," Renewable Energy, vol. 15, pp.562-625, 1998.

[9] J.D. Mondol, Y.G. Yohanis, B. Norton, "Optimising the Economic Viability of Grid-Connected Photovoltaic Systems,” Applied Energy, vol. 86, pp. 985-999, 2009.

[10] N.R. Darghouth, G. Barbose, R.H. Wiser, "Customer-Economics of Residential Photovoltaic Systems (Part 1): The Impact of High Renewable Energy Penetrations on Electricity Bill Savings with Net Metering, "Energy Policy, vol. 67, pp. 290-300, 2014.

[11] T.M.N.T Mansur, N.H. Baharudin, R. Ali, "Technical and Economic Analysis of Net Energy Metering for Residential House," Indonesian Journal of Electrical Engineering and Computer Science, vol. 11, pp.585-592, 2018.

[12] A. Batman, F.G. Bagriyanik, Z.E. Aygen, Ö. Gül, M. Bagriyanik, "A Feasibility Study of Grid-Connected Photovoltaic Systems in Istanbul, Turkey," Renewable and Sustainable Energy Reviews, vol. 16, pp. 5678-5686, 2012.

[13] G.A. Dávi, E. Caamaño-Martín, R. Rüther, J. Solano, "Energy Performance Evaluation of a Net Plus-Energy Residential Building with Grid-Connected Photovoltaic System in Brazil, "Energy and Buildings, vol. 120, pp.1929,2016

[14] O. Ayadi, R. Al-Assad, J. Al-Asfar, "Techno-Economic Assessment of a Grid Connected Photovoltaic System for the University of Jordan,” Sustainable Cities and Society, vol. 39, pp. 93-98, 2018.

[15] A. Allouhi, R. Saadani, T. Kousksou, R. Saidur, A. Jamil, M. Rahmoune, "Grid-Connected PV Systems Installed on Institutional Buildings: Technology Comparison, Energy Analysis and Economic Performance, "Energy and Buildings, vol. 130, pp.188-201, 2016.

[16] H.A. Kazem, T. Khatib, K. Sopian, W. Elmenreich, "Performance and Feasibility Assessment of a 1.4 kW Roof Top Grid-Connected Photovoltaic Power System under Desertic Weather Conditions, "Energy and Buildings, vol. 82, pp. 123-129, 2014.

[17] M.A. Omar, M.M. Mahmoud, "Grid Connected PV-Home Systems in Palestine: A Review on Technical Performance, Effects and Economic Feasibility, "Renewable and Sustainable Energy Reviews, vol. 82, pp. 2490 2497, 2018.

[18] A. Orioli, A.D. Gangi, "Review of the Energy and Economic Parameters Involved in the Effectiveness of GridConnected PV Systems Installed in Multi-Storey Buildings, “Applied Energy, vol. 113, pp. 955-969, 2014.

[19] NREL, HOMER Pro Version 3.7 User Manual, National Renewable Energy Laboratory, 2016, https://www.homerenergy.com.

[20] NASA Langley Research Center, Atmospheric Science Data Center, https://eosweb.larc.nasa.gov.

[21] Lazard, Lazard's Levelized Cost of Energy Analysis - Version 11.0., November 2017

[22] R. Fu, D. Feldman, R. Margolis, M. Woodhouse, K. Ardani, U.S. Solar Photovoltaic System Cost Benchmark: Q1 2017, National Renewable Energy Laboratory, 2017.

[23] A. Sangwongwanich, Y. Yang, D. Sera, F. Blaabjerg, "Lifetime Evaluation of Grid-Connected PV Inverters Considering Panel Degradation Rates and Installation Sites," IEEE Transactions on Power Electronics, vol. 33, pp.1225-1236, 2017.

Optimum Renewable Fraction for Grid-connected Photovoltaic in Office Building... (Ayong Hiendro) 
[24] The Republic of Indonesia, Law of the Republic of Indonesia Number 31 of 2014 Concerning Electricity Tariff, Ministry of Energy and Mineral Resources of the Republic of Indonesia, 2014.

[25] The Republic of Indonesia, Law of the Republic of Indonesia Number 12 of 2017 Concerning Utilization of Renewable Energy Sources for Provision of Electric Power, Ministry of Energy and Mineral Resources of the Republic of Indonesia, 2017.

[26] A.O. Melodi, S.R. Famakin, "A Review of Solar PV-Grid Energy Cost Parity in Akure,South-West Nigeria," International Journal of Electrical and Computer Engineering (IJECE), vol. 5, pp. 879-886, 2015.

[27] Directorate General of Electricity, Emission Factor, Ministry of Energy and Mineral Resources of the Republic of Indonesia, 2015. 